ENTREPRENEURSHIP AND SUSTAINABILITY ISSUES

ISSN 2345-0282 (online) http://jssidoi.org/jesi/ 2020 Volume 8 Number 1 (September)

http://doi.org/10.9770/jesi.2020.8.1(12)
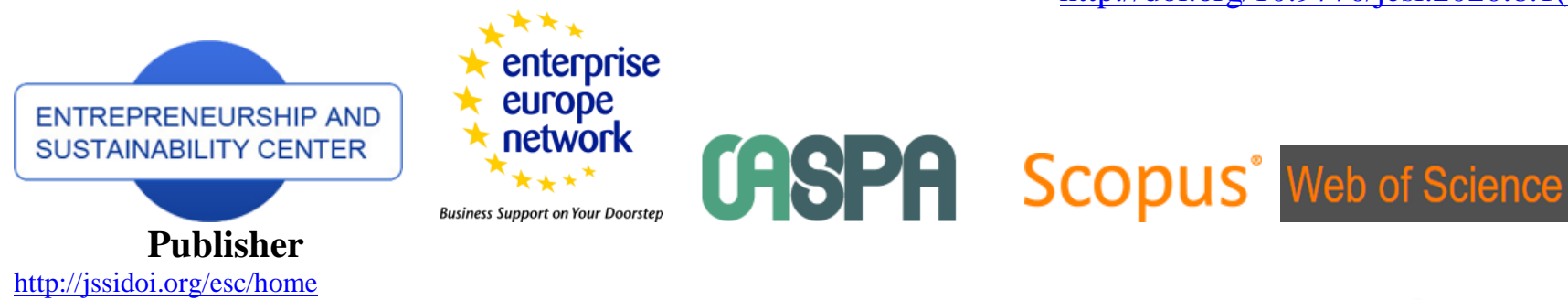

http://jssidoi.org/esc/home

\title{
INNOVATIVE-ENTREPRENEURIAL UNIVERSITIES IN THE POSTMODERN WORLD CONCEPT: POSSIBILITIES OF IMPLEMENTATION
}

\author{
Akmaral Ualzhanova ${ }^{1}$, Dilnara Zakirova ${ }^{2}$, Almaz Tolymbek ${ }^{3}$, \\ Judith J. Hernández G. de Velazco ${ }^{4}$, Ana C. Chumaceiro Hernández ${ }^{5}$ \\ 1,2 Turan University, Satpayev Street, 16a, Almaty, 050013, Kazakhstan \\ ${ }^{3}$ Delta International University, 201 St. Charles Avenue, Suite 2500, New Orleans, LA, 70170, USA \\ ${ }^{4,5}$ Universidad de la Costa, 58 Street \#55-66, Barranquilla, 080002, Colombia
}

E-mails: ${ }^{1} \frac{\text { ualzhanova.a@gmail.com }}{{ }^{2}}{ }^{2} \frac{\text { d.zakirova@turan-edu.kz }}{{ }^{5} \text { anachuma@gmail.com }}{ }^{3}$ tolymbek@gmail.com $;{ }^{4}$ ihernand86@cuc.edu.co;

Received 10 January 2020; accepted 15 June 2020; published 30 September 2020

\begin{abstract}
In the article, they analyze the concepts of innovation and entrepreneurship in the transformation of universities into entrepreneurial institutions, understanding university institutions as organizations that, in a macro concept of their management is represented in its most general expression; that is the production and application of knowledge. In this sense, the characteristic features of commercial, academic activities in innovative and entrepreneurial universities are analyzed, and the optimal organizational and economic mechanisms for the development of this model are studied, in order to use even more positive experience in systems of higher education in countries with less innovative-entrepreneurial development.
\end{abstract}

Keywords: Higher education; entrepreneurial university; innovation activity; transformation.

Reference to this paper should be made as follows: Ualzhanova, A., Zakirova, D., Tolymbek, A., Hernandez, J., Chumaceiro, A. 2020. Innovative-entrepreneurial Universities in the Postmodern World Concept: Possibilities of Implementation. Entrepreneurship and Sustainability Issues, 8(1), 194-202. http://doi.org/10.9770/jesi.2020.8.1(12)

JEL Classification: Q01, Q13, Q18

\section{Introduction}

First, the innovative nature of universities must be understood from the perspective of their central scientific function in the generation of knowledge and in its subsequent applications or praxis that gives entrepreneurship an operational character.

\section{The praxis of innovation}

From a diachronic perspective, it is assumed that the continued advance of science and technology has occurred from the significant innovations of humanity oriented to the detection and resolution of problems, transforming society and our patterns of life, as well as improving the quality of life, the sustainability of resources and the welfare of the people. However, science has been debated between two alternative policies. On the one hand, to 


\section{ENTREPRENEURSHIP AND SUSTAINABILITY ISSUES}

ISSN 2345-0282 (online) http://jssidoi.org/jesi/

2020 Volume 8 Number 1 (September)

http://doi.org/10.9770/jesi.2020.8.1(12)

continue being the primary market tool which reigns in the world economy and on the other, to produce knowledge and technologies that promote the welfare of the people.

It is also relevant to highlight that both institutional, technological, and human capacities must be used efficiently and strategically, which constitute a form of skills that proactively solve problems to improve processes and generate new products and services, definitely relying on innovation to encourage new creation and thus establish a strategic direction for entrepreneurship.

Based on the previous evidence, it can be inferred that the societies that have these capacities have a national innovation system, a situation that also requires the establishment of a reliable educational system that privileges basic scientific training and that reaches all sectors of the society. Such a system is indispensable for countries to enjoy a society that is not only modern but more just, which provides a new technological base for the new generations. Recognize entrepreneurship as a mechanism for the spill of knowledge, recovering the connection between new knowledge, innovation, and economic growth (Sánchez et al.; 2015). (Nuñez and Ravina: 2017; Ramirez et al.: 2019).

Corresponding to these approaches, Jaimes (1998), he points out that it is undeniable that technological, scientific development cannot be achieved without building a minimum of scientific culture. This achievement is understood by developed countries that support the incorporation of scientific education from the first educational level as vital.

With research and development skills, the stronger these skills are, and the greater access to complementary assets by the competition, the higher the chances of imitating a given innovation. In this regard, Porter (2006) states that the remarkable innovation production capacity of Israeli companies is not only due to more efficient technology management, but also the favorable environment in Israel for innovation, including strong links between industry and University, and a large group of scientists and engineers with excellent training.

Countries with less industrial development have lagged behind other regions of the world in innovation and entrepreneurship, among other reasons; They fail to insert themselves competitively in other markets, they do not have the required technology or the necessary investment in research and development of new products.

These considerations lead to infer that innovation must be managed efficiently by organizing both technical and economic human resources to increase the creation of new knowledge, generating ideas that allow obtaining new management methods, production processes aimed at achieving competitiveness of the organization.

In order to achieve advances in innovation, it is necessary to realize more resources in research and development; but above all, the application of resources in the potential of competitiveness must be sought by establishing strong links between the company, the University and the public administration, that creativity is what can allow innovative projects or entrepreneurial applications to be carried out.

Problems related to financing and maintaining the competitiveness of modern higher education have deepened throughout the world as a result of economic crises and a gradual reduction of social programs, including budgetary financing of educational institutions. This problem is especially urgent for Kazakhstan, Russia, other post-Soviet states and in Latin America, due to difficulties of transformation in the course of political, public, and economic changes. The situation is not unique and must be considered in the global context of the transformations in the institutional base of higher education.

The experience accumulated while studying the economics of universities in economically developed countries shows that the educational, research, production, and technological components are essential, but they are not the only source of their income (Table 1). 


\section{ENTREPRENEURSHIP AND SUSTAINABILITY ISSUES}

ISSN 2345-0282 (online) http://jssidoi.org/jesi/ 2020 Volume 8 Number 1 (September) http://doi.org/10.9770/jesi.2020.8.1(12)

Table 1. Breakdown of global leading universities' income, 2012, \% (Policano \& Fethke, 2012)

\begin{tabular}{|c|c|c|c|c|c|}
\hline University & $\begin{array}{c}\text { Income from } \\
\text { educational } \\
\text { services }\end{array}$ & $\begin{array}{c}\text { Income from } \\
\text { investment/ } \\
\text { endowment fund }\end{array}$ & $\begin{array}{c}\text { Grants and } \\
\text { contracts }\end{array}$ & $\begin{array}{c}\text { Income from } \\
\text { goods sold and } \\
\text { services provided }\end{array}$ & $\begin{array}{l}\text { Other } \\
\text { income }\end{array}$ \\
\hline Harvard & 19 & 35.2 & 21 & - & 24.8 \\
\hline Yale & 9 & 35 & 25 & 20 & 11 \\
\hline Stanford & 12.1 & 21.9 & 31 & 13.7 & 11.3 \\
\hline $\begin{array}{c}\text { Massachusetts Institute of } \\
\text { Technology }\end{array}$ & 10 & 24 & 49 & - & 17 \\
\hline Princeton & 19 & 46 & 18 & - & 17 \\
\hline University of Texas & 10 & 7 & 19 & - & 64 \\
\hline University of St. Thomas & 59 & 19 & 1 & - & 21 \\
\hline Kansas State University & 24 & 1 & 22 & - & 53 \\
\hline University of Alberta & 27.8 & 2.5 & 7.4 & 43.9 & 18.4 \\
\hline
\end{tabular}

However, recognized research universities in the USA, the United Kingdom, Western Europe, and other countries obtain additional funds by providing services to external clients, including by leasing their high-tech infrastructure, providing research advice, and conducting evaluations of professional experts with the help of leading scientists. Donations from charities, graduates, and study fees (especially from international students) are also an essential source of income for universities and accumulate in donation funds.

In the EE. UU., The United Kingdom and other economically developed countries, universities, together with training and research, carry out entrepreneurial activities (Policano and Fethke, 2012; Zoltan, 2006) and various innovation activities in higher education and for educational and scientific support of society (Alvarez and Busenitz, 2001; Lambooy, 1997; Onakoya and Abosede, 2013; Girdzijauskaite et al., 2019). Russia's experience related to the development of entrepreneurial universities is also enjoyable. (Table 2) (Mesto rozhdenia tekhnologicheskih innovatsii, n.d.).

Table 2. Top 10 university startups in terms of investment drawn into a specific startup company (mesto rozhdenia tekhnologicheskih innovatsii, n.d.)

\begin{tabular}{|c|c|c|}
\hline Startup company & University & $\begin{array}{c}\text { Investment injected into the } \\
\text { startup company (USD million) }\end{array}$ \\
\hline Telegram Messenger & Saint Petersburg State University & $1,700.00$ \\
\hline Slack & Siberian State Industrial University & $1,216.95$ \\
\hline DST Global & Lomonosov Moscow State University & 688.00 \\
\hline Revolut & Moscow Institute of Physics and Technology. Russian School of & 336.44 \\
\hline Evernote & Economics & 290.00 \\
\hline Mirantis & Lubkin Russian State University of Oil and Gas & 220.00 \\
\hline Brain Corporation & Lomonosov Moscow State University & 125.00 \\
\hline WorkFusion & Moscow Institute of Physics and Technology & 121.30 \\
\hline KupiVIP & Financial University under the Russian Government & 119.6 \\
\hline Turbonomic & MIREA - Russian University of Technology, Bauman Moscow State & 117.5 \\
\hline
\end{tabular}

Source: compiled by authors

A substantial result of the combination of entrepreneurship, university studies, and production is the establishment of successful university companies (Toivonen and Vasiliev, 2010) that efficiently implement the idea of cooperation between universities, manufacturers, and the State (Braunerhjelm, 2008). 


\section{ENTREPRENEURSHIP AND SUSTAINABILITY ISSUES}

ISSN 2345-0282 (online) http://jssidoi.org/jesi/ 2020 Volume 8 Number 1 (September) http://doi.org/10.9770/jesi.2020.8.1(12)

Under the conditions of a global educational environment, the functions of modern universities are transformed and diversified as they begin to play the role of active participants in economic relations, gradually expanding their entrepreneurial functions. The essential prerequisites for the development of entrepreneurial aspects in university activities are the limited state funding of the higher education system, the need to diversify the sources of funding and the current relevance of linking academic education, science and the business sector ( Lipina et al., 2017; Karmanov et al., 2016).

Universities should solidify and diversify their activities to not only to perform efficiently but also to gain leadership in a global educational environment. The entrepreneurial and international aspects, therefore, penetrate all the critical areas of activities in modern universities (Table 3).

Table 3. Transformation of universities' functions

\begin{tabular}{|c|c|c|}
\hline Traditional functions & Entrepreneurial activity & International activity \\
\hline $\begin{array}{c}\text { Educational, teaching } \\
\text { activities }\end{array}$ & $\begin{array}{c}\text { Diversification of services (programs of various duration, } \\
\text { levels, learning technologies); a wider scope of core and } \\
\text { related paid services }\end{array}$ & $\begin{array}{c}\text { Active attraction of school leavers and } \\
\text { consumers in external markets }\end{array}$ \\
\hline $\begin{array}{c}\text { Research and } \\
\text { development }\end{array}$ & $\begin{array}{c}\text { A wider scope of R\&D; commercialization of research results; } \\
\text { a broader array of related intellectual services (consulting); the } \\
\text { establishment of scientific parks, technology parks, technology } \\
\text { cities, business incubators attached to universities }\end{array}$ & $\begin{array}{c}\text { Academic mobility; participation in } \\
\text { international scientific projects; publication } \\
\text { of results in international journals; } \\
\text { participation in consortiums of universities } \\
\text { when executing international scientific } \\
\text { educational projects }\end{array}$ \\
\hline $\begin{array}{c}\text { Marketing activities } \\
\text { Financial and economic } \\
\text { activities }\end{array}$ & $\begin{array}{c}\text { Aggressive advertising campaigns at national and international } \\
\text { levels; search of potential donators; activities focused on } \\
\text { graduates as potential donators; participation in universities' } \\
\text { national and global ratings }\end{array}$ & $\begin{array}{c}\text { Search and diversification of additional funding sources; the } \\
\text { formation of an endowment fund; broader financial autonomy }\end{array}$ \\
$\begin{array}{c}\text { Search for foreign investors and partners; a } \\
\text { wider scope of exports related to } \\
\text { educational and other services }\end{array}$ \\
\hline
\end{tabular}

Source: Compiled by the authors based on (Policano \& Fethke, 2012, Zoltan, 2006, Alvarez \& Busenitz, 2001; Lambooy, 1997; Onakoya \& Abosede, 2013; Toivonen \& Vasiliev, 2010; Braunerhjelm, 2008).

Previous processes aimed at diversifying university functions laid the foundations for the emergence of entrepreneurial universities, which are characterized by widely diversified traditional and modern functions.

However, Kazakhstan, as noted by the president of the Management University of Almaty (ALMA University), Asylbek Kozhakhmetov, has taken a model, according to which the conditions for the economy of innovation are formed by the government and companies without the participation of universities, although the successful experience of other countries shows that conditions must be formed jointly by the State, companies, and universities (Predprinimatelstvo i innovatsii, nd). Sustainable development of innovation should not be expected if there is no interaction with universities.

In Latin America, the contribution of public universities in the economic development of Latin America with the coordinated support of the State and the private sector has been studied. Since 1980 to the XXI century, several mechanisms have experienced a more considerable boom to transfer knowledge to society, such as; creation and promotion of innovative, productive ventures, business incubators, spin-offs, Science and Technology Parks, and the effective triple helix entrepreneurship linkage.

\section{Methods}




\section{ENTREPRENEURSHIP AND SUSTAINABILITY ISSUES}

ISSN 2345-0282 (online) http://jssidoi.org/jesi/ 2020 Volume 8 Number 1 (September) http://doi.org/10.9770/jesi.2020.8.1(12)

In the course of the investigation, we use two perspectives of interpretation for the results; a critical, descriptive review of the factors (categories) of analysis; and the expert survey method, with 25 experts involved, 15 of them are employees of universities, which are members of the Association of Entrepreneurial Universities of Kazakhstan (Universities of Turan and Turan-Astana), and five work for the organization without KPMATS profit (the Chapter of the Triple Helix Association of Kazakhstan). This group of experts is directly related to the introduction of the Triple Helix concept and the principles of entrepreneurship in the Kazakh educational space.

Several questions were asked to experts about the factors for the operation of a business university and the areas in which it can operate.

\section{Results}

Based on the survey results, entrepreneurial universities are characterized by the following key factors.

Table 4. Factors for the operation of an entrepreneurial university

\begin{tabular}{|c|c|c|c|}
\hline \# & Factors & $\begin{array}{l}\text { Topicality for Kazakhstan } \\
(\% \text { mentioned })\end{array}$ & Rank \\
\hline 2 & Integrated (corporate) entrepreneurial culture & $84 \%$ & 2 \\
\hline 4 & $\begin{array}{c}\text { Presence of employees in charge of implementation who are highly- } \\
\text { professional }\end{array}$ & $72 \%$ & 4 \\
\hline 5 & Support from the environment (civil society) & $64 \%$ & 5 \\
\hline
\end{tabular}

Source: Compiled by the authors based on the conducted survey.

Experts believe that the generation of entrepreneurial ideas based on the creative use of current experience and the development of innovation projects is a separate and critical area of activities for a modern business university. According to a KPMATS employee (33 years old), "as people with entrepreneurial character traits, entrepreneurial inclinations, and business thinking, they do not represent more than 4-6\% of the total population, and in the education system, their percentage compared to the main academic, The research and auxiliary staff may be a little higher (due to greater literacy and inclination to the areas of research in science, technology, and education), it is enough for a business university to have a small group of such entrepreneurs ( up to $10 \%$ of total employees) ".

A primary condition necessary for success, as most respondents think, is the presence within the University of a director (rector, vice-rector) with an entrepreneurial vision and preferably with entrepreneurial skills. The other critical condition is the exchange of entrepreneurial ideas by all (or the overwhelming majority) of university staff members when employees really support the University's entrepreneurial policy and programs, work hard and feel responsible for the results. Successful entrepreneurial activities can only be carried out if participants in the creative process (a wide range of areas in which university employees participate) have an entrepreneurial culture.

The next condition is the presence of a group of critical entrepreneurs who generate business ideas and participate in the development of entrepreneurial projects, have unlimited freedom in the creative search, and enjoy the support of academic staff. The group of entrepreneurs of a university (business division), as the experts and employees of the University believe, can consist of people from presidents, laboratories, other divisions that can take their entrepreneurial search actions directly at their desks, on the premises especially designed or in the capacity of an "entrepreneurial section" attached to the founding council (board of directors), the university administration and the academic council of the University, with new ideas and entrepreneurial projects that will be published compulsorily, discussed and accepted by the entire University. 


\section{ENTREPRENEURSHIP AND SUSTAINABILITY ISSUES}

ISSN 2345-0282 (online) http://jssidoi.org/jesi/

2020 Volume 8 Number 1 (September)

http://doi.org/10.9770/jesi.2020.8.1(12)

Experts point out that fruitful cooperation between universities and the industrial sector is essential if the State supports the relatively rapid launch of the creative activities of universities in mass production. The solution of this problem will allow to expand the technological research and intellectual potential of a region (country) and produce a positive impact on the economic development of the State.

Undoubtedly, a decisive factor for success or failure on the road to transforming universities into entrepreneurial institutions, as experts think, is the impact of the environment in which a university operates (attendance, neutral position (or indifference) or counteract). According to the associate professor of the University of Turan (37 years old), "it is essential for civil society to have the entrepreneurial mindset: support (at least moral) from the State and ordinary people of business lifestyle and entrepreneurial spirit as a necessary factor of economic growth. " To this end, the University organizes the summer school Turan Emprendimiento, with measures taken to promote and form the positive image of the creative class of entrepreneurs.

Experts believe that the last important factor is the application of innovative training methods, advanced educational and professional programs, various courses and disciplines, interdisciplinary and multidisciplinary approaches to training, state-of-the-art equipment, the latest devices, and technologies, aimed at involving to students and postgraduates (doctoral students) in research as much as possible.

Consequently, the results of the survey show that the real innovation policy helps to transform universities into entrepreneurial institutions. Innovation relationships arise among the academic staff of a university in the course of entrepreneurial changes. The nature of these relationships can contribute to or oppose the introduction of entrepreneurial ideas into a university.

\section{Discussion}

According to G. Itzkovitz, founder of the Triple Helix concept that visited Kazakhstan in 2015, for the successful interaction of the State, companies, and universities, Kazakhstan has everything it needs: natural resources, possibilities to develop new industries, solid educational base, and stable political environment. Indeed, many efforts and time will be required, and it may be so that, on this issue, it will be essential to cooperate with other countries, which pursue this approach and apply various combinations, for example, with Russia (Univestitety sozdaut novye industrii i razvivaut biznes, n.d ).

In this sense, there is a quite exciting and useful experience obtained by the Tomsk State University of Electronic Administration and Radio (TUSUR) (Nauka i innovatsii, nd) and Turan University (Almaty) (Islamgulova, et al., 2016) with relation to the development of innovation and commercialization of research results.

This results relate to the formation of an entrepreneurial culture in a university from the first years of study, with the introduction of a unique educational technology (group project training), whose essence is to build an educational process, from the second or 3rd year of study, based on real scientific projects executed by students' creative teams (5-7 people). This organization of studies gives talented students the possibility of self-realization in the student business and technology incubators of the University (the Druzhba student business incubator and the Technology Business Incubator). Turan University launched a similar business incubator in October 2016 (Islamgulova, et al., 2016).

Tomsk University builds mutual relationships with knowledge-intensive companies based on a scientific innovation training center (TSIC), which constitutes an association of companies established by university graduates and a belt of its innovation circle. Currently, TSIC includes more than 150 companies that produce approximately $80 \%$ of the knowledge-intensive articles in the region (Nauka i innovatsii, n.d.). The practical training center Turan Alatau, a joint project of the Alatau Technology Park, Eltex Alatau and the Turan 


\section{ENTREPRENEURSHIP AND SUSTAINABILITY ISSUES}

ISSN 2345-0282 (online) http://jssidoi.org/jesi/

2020 Volume 8 Number 1 (September)

http://doi.org/10.9770/jesi.2020.8.1(12)

University, carries out activities within an exclusive economic zone (the Innovation Technology Park) (Islamgulova, et al., 2016).

As part of TSIC, the University of Tomsk cooperates with companies in various ways (commercialization of R\&D of the University, opening of chairs and joint laboratories, external internships in companies and conferences given by corporate employees, financing of associated companies). As of today, five of the University's eight research institutes have been established through the support of TSIC, and from 2010 to 2018 , the University executed nine significant projects in cooperation with industrial partners (in seven of which the University He was a principal contractor, with a budget of more than 3.5 billion rubles) (Nauka i innovatsii, sf).

International cooperation is not minor. Turan University joined the Helix Triple Association in March 2017 and became the headquarters of its representative office (Chapter of the Helix Kazakhstan Triple Association). In 2018, the University participated in HEInnovate, an EU project (with the support of the OECD Secretariat) that was developed as a tool for self-evaluation of higher education institutions that wish to explore their entrepreneurial and innovation potential ( Islamgulova, et al., 2016).

\section{Conclusion}

We analyze the transformational changes in traditional (research) universities towards their transformation into entrepreneurial institutions; We determine the main factors for carrying out the successful academic entrepreneurial activities of a university.

The materialization of more considerable resources in research and development is required, but above all, the application of resources in the potential of competitiveness must be sought by establishing strong links between the company, the University, and the public administration, that creativity is what can allow carry out innovative projects. Implement a scientific culture that must prevail in the education system in order to achieve a more equitable society. From this perspective, innovation and entrepreneurship must be directly related to the general technological policy and the approaches and models of economic, social, and cultural development that must be managed by the actors that make up the system.

The experience of positive activities carried out by foreign universities, including Russian entrepreneurial universities, their stable economic status, the permanent strengthening of their positions in the world markets for educational and scientific services, high competitiveness and the achievement of substantial results in education, science and technology certify that entrepreneurial activities can also provide universities with not only economic success, but also scientific-technical development in the future. The funds derived from the commercialization of results can be reinvested in the improvement and expansion of all University activity areas. The transformation of universities and their business activities require close cooperation with the industrial sector and government and the creation of the entrepreneurial mindset necessary in society and their active support.

\section{References}

Alvarez, S.A. \& Busenitz, L.W. 2001. The entrepreneurship of resource-based theory. Journal of Management, 27, 755-775.

Braunerhjelm, P. 2008. Entrepreneurship, Knowledge, and Economic Growth. Foundations and Trends in Entrepreneurship, 4(5), 451533.

Girdzijauskaite, E., Radzeviciene, A., Jakubavicius, A. 2019. Impact of international branch campus KPIs on the university competitiveness: FARE method. Insights into Regional Development, 1(2), 171-180. https://doi.org/10.9770/ird.2019.1.2(7) 


\section{ENTREPRENEURSHIP AND SUSTAINABILITY ISSUES}

ISSN 2345-0282 (online) http://jssidoi.org/jesi/ 2020 Volume 8 Number 1 (September)

http://doi.org/10.9770/jesi.2020.8.1(12)

Islamgulova, S.K., Parshina, G.N. \& Tusupova, S.A. 2016. Formirovanie universiteta predprinimatelskogo tipa kak uslovie postroenia obshchestva vseobshchego truda [The formation of a university of the entrepreneurial type as a condition for the building of the society of universal labor]. Proceedings of the international conference "The entrepreneurial university as a modern form of interaction among public authorities, businesses, education and science».

Jaimes, R. (1998). Origin and destination of scientific knowledge. Fondo Editorial. Tropykos Caracas.

Karmanov, M.V., Korotkov, A.V., Gryzunova, N.V., Kiseleva, I.A. \& Kuznetsov, V.I. 2016. The strategic analysis of industry-specific competition and environmental risks - an integrated approach. International Journal of Environmental and Science Education, 11(18), 12657-12667.

Lambooy, J. G. 1997. Knowledge production, organisation and agglomeration economies. Geo Journal, 41(4), $293-300$.

Lipina, S.A., Lochan, S.A., Fedyunin, D.V. \& Bezpalov, V.V. 2017. Government promoting communication tool in innovation development of companies. European Research Studies Journal, 20(4V), 536-547.

ME Porter, MR Kramer (2006) The link between competitive advantage and corporate social responsibility. Harvard business review, 7893 https://www.comfama.com/contenidos/servicios/Gerenciasocial/html/Cursos/Columbia/Lecturas/Strategy-Society.pdf

Mesto rozhdenia tekhnologicheskih innovatsii. n.d. [Place of birth of technology innovation]. Retrieved March 01, 2019, from http://www.acexpert.ru/articles/mesto-rozhdeniya-tehnologicheskih-innovaciy.html

Nauka i innovatsii [Science and innovation]. n.d. Retrieved March 01, 2019, from https://tusur.ru/ru/nauka-i-innovatsii

Núñez, Estela y Ravina, Rafael (2017). Analysis of the level of business competitiveness in the Colombian advertising landscape based on creative success and ethical and legal responsibility. JURÍDICAS CUC 13(1), 9-28. http://dx.doi.org/10.17981/juridcuc.13.1.2017.1

Onakoya, A.B. \& Abosede, A.J. 2013. The common thread amongst entrepreneur, manager and capitalist: A theoretical approach. International Journal of Social Sciences and Entrepreneurship, 1(3), 481-496.

Policano, A.J. \& Fethke, G.C. 2012. Public No More. A New Path to Excellence for America's Public Universities. Stanford, CA: Stanford Business Books.

Predprinimatelstvo $i$ innovatsii [Entrepreneurship and innovation]. n.d. Retrieved March 01, 2019, from https://www.almau.edu.kz/predprinimatelstvo_i_innovacii-6392

Ramírez-García, A., Monterroso-Rivas, A., \& Garcia-Espejel, A. (2019). Characterization of the innovation network of small livestock producers in the state of Sonora, México. ECONÓMICAS CUC, 40(2), 195-216. https://doi.org/10.17981/econcuc.40.2.2019.12

Sánchez Tovara, Yesenia, Francisco García Fernándeza, y José Esteban (2015). The capacity for innovation and its relationship with entrepreneurship in the regions of Mexico. Management Studies, 31, July-September, 243-252 http://dx.doi.org/10.1016/j.estger.2015.04.001

Toivonen, N.R. \& Vasiliev, V.N. 2010. Issledovatelskii i/ili predprinimatelskii. Kakie universiteti sozdautsia v Rossii? [Research and/or entrepreneurial. What universities are founded in Russia?]. Innovation, 5(139), 80-86.

Univestitety sozdaut novye industrii i razvivaut biznes [Universities create new industries and develop business] (n.d.) Retrieved March 01, 2019, from https://forbes.kz/process/education/po_troynoy_spirali_1/

Zoltan, J. (2006). Acs. How is entrepreneurship good for economic growth? Innovations: Technology, Governance, Globalization, 1(1), 97107. 


\section{Akmaral UALZHANOVA}

ORCHID ID: orcid.org/0000-0003-2858-4741

Dilnara ZAKIROVA

ORCHID ID: orcid.org/0000-0001-5161-959X

Almaz TOLYMBEK

ORCHID ID: orcid.org/0000-0002-3318-2109

Judith J. HERNÁNDEZ

ORCHID ID: orcid.org/0000-0002-5621-9496

Ana CHUMACEIRO

ORCHID ID: orcid.org/0000-0002-8539-2853

Register for an ORCID ID:

https://orcid.org/register

Copyright (C) 2020 by author(s) and VsI Entrepreneurship and Sustainability Center

This work is licensed under the Creative Commons Attribution International License (CC BY).

http://creativecommons.org/licenses/by/4.0/

c) (†) Open Access 